Atmos. Chem. Phys. Discuss., 11, 16599-16610, 2011

www.atmos-chem-phys-discuss.net/11/16599/2011/

doi:10.5194/acpd-11-16599-2011

(C) Author(s) 2011. CC Attribution 3.0 License.

\title{
Sensing Hadley cell with space lidar
}

W. Sun ${ }^{1}$ and B. Lin ${ }^{2}$

${ }^{1}$ Science Systems and Applications, Inc., Hampton, Virginia 23666, USA

${ }^{2}$ NASA Langley Research Center, Hampton, Virginia 23681, USA

Received: 3 May 2011 - Accepted: 31 May 2011 - Published: 10 June 2011

Correspondence to: W. Sun (wenbo.sun-1@nasa.gov)

Published by Copernicus Publications on behalf of the European Geosciences Union.

\section{ACPD}

$11,16599-16610,2011$

Sensing Hadley cell with space lidar

W. Sun and B. Lin

Title Page

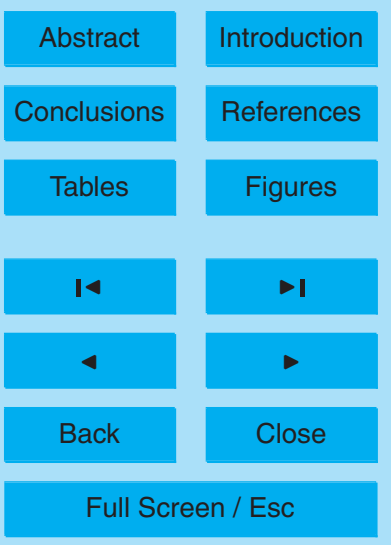

Printer-friendly Version

Interactive Discussion 


\section{Abstract}

This letter shows that the extent of the Hadley cell could reliably be estimated by measuring the height of the uppermost super-thin clouds in the troposphere with spaceborne lidar. Through consecutive multi-year measurements of the height of the upper-

5 most super-thin clouds, a good estimation of the expansion of the Hadley cell could be obtained.

\section{Introduction}

Some recent studies reported expansion of the Earth's tropical regime in the past few decades due to the global warming of the planet (Quan et al., 2004; Frierson et al.,

10 2007; Lu et al., 2007; Seidel et al., 2007; Johanson and Fu, 2009; Fu and Lin, 2011). Because of the prevalence of precipitation in the tropical belt, this expansion, if true, has very important implications to the climate of dry subtropical regions. The precipitation in the tropical regions is largely determined by the Hadley cell, an atmospheric circulation pattern that dominates the tropical atmosphere as illustrated in Fig. 1, with rising air near the equator, poleward air-mass transport in the upper troposphere, descending motion in the subtropics, and equatorward air-mass transport by the prevailing trade wind in the lower troposphere. The ascending part of the Hadley cell carries moisture into upper atmospheric layers and thus promotes clouds and rain in the deep tropical regions, whereas air in the descending part is significantly drier and results in the deserts in the subtropical belt. The poleward expansion of the Hadley cell is a strong indication of the warming of the globe (Quan et al., 2004; Frierson et al., 2007; Lu et al., 2007; Seidel et al., 2007; Johanson and Fu, 2009).

The extent of the Hadley cell has been studied by analyzing satellite observations of atmospheric ozone concentration (Hudson et al., 2006) and stratospheric and tropospheric temperature (Fu et al., 2006), studying the tropopause height change with radiosonde and model (Seidel and Randel, 2007), locating the latitude of zero net wind

Sensing Hadley cell with space lidar

W. Sun and B. Lin

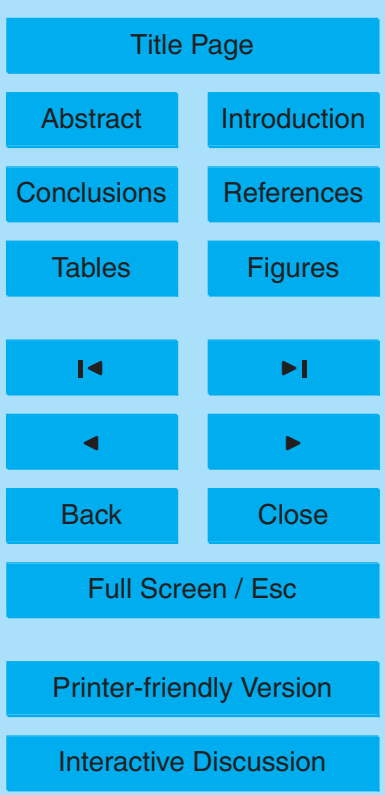


by model-reanalysis data ( $\mathrm{Hu}$ and $\mathrm{Fu}, 2007)$, and using satellite infrared data to find the dry subsidence regions at the edges of the Hadley cell (Hu and Fu, 2007). Limited either by low spatial and temporal sampling observations such as in Seidel and Randel (2007) and $\mathrm{Hu}$ and $\mathrm{Fu}$ (2007) or by uncertainties in the Hadley cell studies introduced 5 by indirect retrieval approaches such as in Hudson et al. (2006) and Fu et al. (2006), the methods for determination of the Hadley circulation especially its extent still need to be improved.

\section{Method and data}

In this section, we report a novel way to measure the extent of the Hadley cell based on a direct space-borne lidar observation of optically super-thin clouds.

Optically thin clouds cover $\sim 50 \%$ of the globe. The Central Equatorial Pacific Experiment (CEPEX) and the Tropical Ocean Global Atmosphere Coupled OceanAtmosphere Response Experiment (TOGA COARE) found a thin layer of cirrus near the tropopause (Spinhirne et al., 1996). Using Nimbus-4 Infrared Interferometer Spec15 trometer (IRIS) measurements and the Stratospheric Aerosol Gas Experiment (SAGE) II measurements, Prabhakara et al. (1993) and Wang et al. (1994) observed thin cirrus near the tropopause more than $50 \%$ of the time in warm pool regions. Using a lidar operating in Chang-Li, Taiwan, China, Nee et al. (1998) found thin cirrus occurring approximately $50 \%$ of the time at $25^{\circ} \mathrm{N}$. Using lidar, Platt et al. (1998) also detected thin cirrus with optical thickness as low as 0.01 in Kavieng, Papua, New Guinea. During the Lidar In-space Technology Experiment (LITE), Winker and Trepte (1998) found horizontally homogeneous layers of cirrus in thin sheets near the tropical tropopause with thicknesses between a few hundred meters and one kilometer. Moreover, using the High Resolution Infrared Radiation Sounder (HIRS) Wylie and Menzel (1998) reported that thin clouds were found in $42-44 \%$ of global observations. However, passive remote sensing techniques such as the Moderate Resolution Imaging Spectroradiometer (MODIS) (King et al., 1992) generally fail to detect optically thin clouds with an optical

\section{ACPD}

$11,16599-16610,2011$

Sensing Hadley cell with space lidar

W. Sun and B. Lin

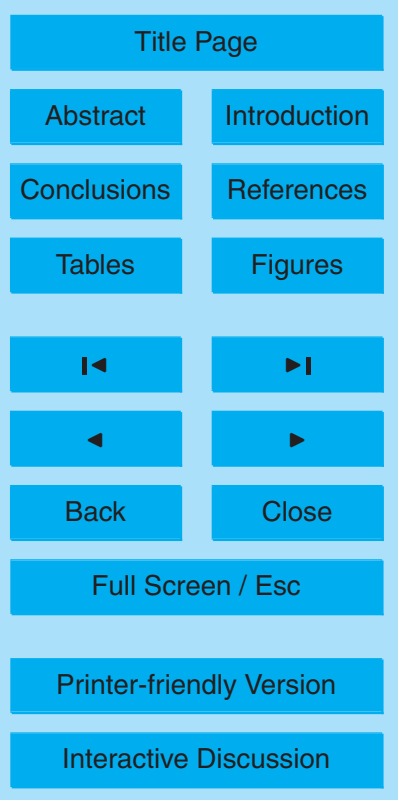


thickness at the wavelength of $0.55 \mu \mathrm{m}$ smaller than $\sim 0.3$ (Minnis et al., 2008). These super-thin clouds are hard to identify on satellite images because they either reflect too little solar radiation or block too little terrestrial emission. Therefore, active optical sensors such as the lidar on the Cloud-Aerosol Lidar and Infrared Pathfinder Satellite 5 Observation (CALIPSO) satellite (Winker et al., 2003) are usually used to detect these clouds such as the uppermost thin cirrus in Fig. 2.

One of the distinct features of the atmosphere in Hadley cell is the significant moisture transport from equatorial areas to subtropical regions. Deep convection over equatorial areas transports moisture to upper troposphere. The Hadley circulation brings 10 the moisture from low latitudes to relatively higher latitudes. The longwave radiation cooling and uplifting of the moist air could form very thin cirrus layer at upper troposphere near tropopause during the moisture transport. At the subsidence zones, the downward motion of the Hadley cell makes the moist air warmer and drier, where the supper-thin cirrus layer disappears when descending to certain altitude. Therefore, 15 the extent of Hadley cell could be directly observed by tracing the super-thin clouds' range. Our hypothesis here to link the super-thin clouds to the extent of Hadley cell is that the super-thin clouds near tropopause are directly from the radiation cooling of the upper-troposphere moisture carried by the general circulation; but common clouds, significantly affected by local thermodynamic conditions, cannot be used for tracing the large-scale air flow in the general circulations. Therefore super-thin clouds that cannot be detected by MODIS but can be identified by CALIPSO lidar are studied in this work. In this study, one-year CCCM data (1 January-31 December 2007), which merges the measurements from the Clouds and the Earth's Radiant Energy System (CERES) (Wielicki et al., 1996), CALIPSO, CloudSat (Stephens et al., 2002), and MODIS, are 25 used. In each CERES nadir field of view (FOV) of the CCCM data, we have MODIS cloud fraction, CALIPSO cloud fraction, and cloud heights from both CALIPSO and MODIS measurements. The CERES FOVs of super-thin clouds are those with MODIS cloud fraction smaller than $1 \%$ and CALIPSO cloud fraction of $100 \%$. Statistics on the one-year data shows that $\sim 10 \%$ of the CERES FOVs are classified as clear sky by the

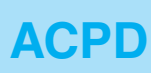

$11,16599-16610,2011$

Sensing Hadley cell with space lidar

W. Sun and B. Lin

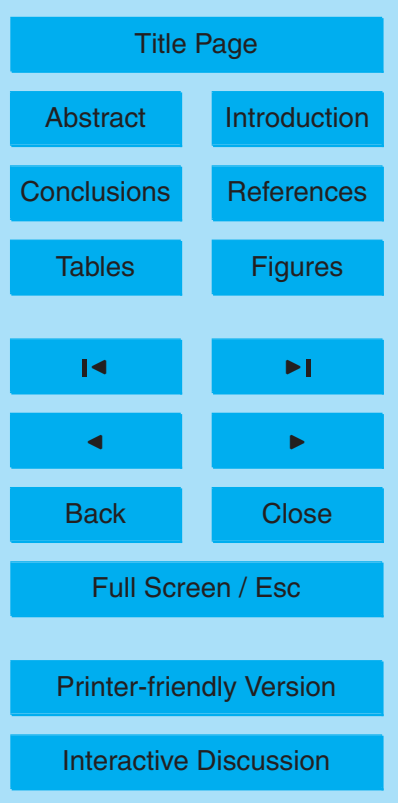


MODIS (i.e., MODIS cloud fraction $<1 \%$ ), among which $~ 50 \%$ of the CERES FOVs are actually covered by the super-thin clouds.

\section{Result}

Figure 3 shows the one-year zonal mean of the maximum height of the super-thin 5 clouds for nighttime oceans. We use only nighttime data because CALIPSO lidar measurements involve no sunlight noise at night. To avoid the interference from strong local convections over land, we limit our sampling regions simply over oceans. We can see that the maximum cloud heights of the super-thin clouds well correlate with the Hadley cells. Within the colatitude range of $67^{\circ}$ to $110^{\circ}\left(23^{\circ} \mathrm{N}\right.$ to $\left.20^{\circ} \mathrm{S}\right)$, limited by the tropopause, the mean maximum super-thin cloud heights are homogeneously around $15.5 \mathrm{~km}$, only slightly higher in the southern Hadley cell than in the northern Hadley cell due to the warmer condition over southern ocean. At colatitudes $67^{\circ}$ and $110^{\circ}\left(23^{\circ} \mathrm{N}\right.$ and $20^{\circ} \mathrm{S}$ ), the cloud height drastically decreases. This is due to the downward air flow in the Hadley cells. Therefore, the latitude range of the horizontally homogeneous-

15 height super-thin clouds could be considered as a metric to evaluate the extent of the Hadley cell. Figure 4 shows the one-year zonal mean of the height of common ice clouds from MODIS infrared imager for nighttime oceans. It can be seen that common clouds do not have homogeneous-cloud-height feature in the Hadley cells which could be used as a metric to indicate the extent of the general circulation.

\section{Conclusions}

Our results show that the extent of the Hadley cell could reliably be estimated by measuring the height of the uppermost super-thin clouds in the troposphere with spaceborne lidar. In this study, we focus on the super-thin clouds which cannot be detected by the passive imagers such as MODIS, because these thin clouds could trace the

Sensing Hadley cell with space lidar

W. Sun and B. Lin

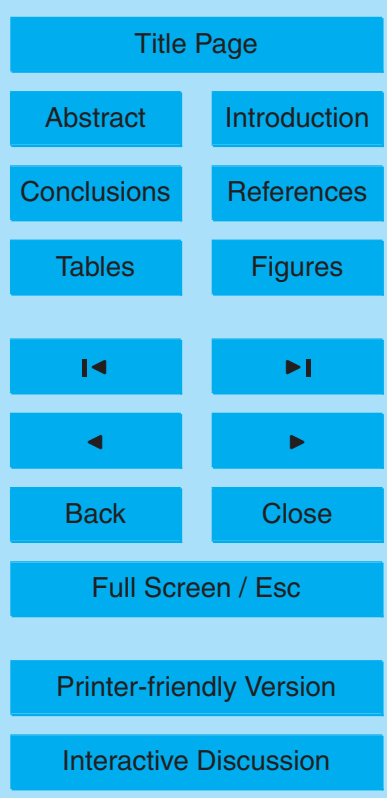


moisture flow in the general circulations. Through consecutive multi-year measurements of the height of the uppermost super-thin clouds, a good estimation of the expansion of the Hadley cell could be obtained.

Acknowledgement. This study is supported by NASA CLARREO and Glory missions. The 5 authors thank Bruce A. Wielicki, David F. Young, Michael I. Mishchenko, and Hal Maring for their help on this work.

\section{References}

Frierson, D. M. W., Lu, J., and Chen, G.: Width of the Hadley cell in simple and comprehensive general circualtion models, Geophys. Res. Lett., 34, L18804, doi:10.1029/2007GL031115, 102007.

Fu, Q. and Lin, P.: Poleward shift of subtropical jets inferred from satellite-observed lower stratospheric temperature, J. Climate, doi:10.1175/JCLI-D-11-00027.1, 2011.

Fu, Q., Johanson, C. M., Wallace, J. M., and Reichler, T.: Enhanced mid-latitude tropospheric warming in satellite measurements, Science, 312, 1179, doi:10.1126/science.1125566, 2006.

$\mathrm{Hu}, \mathrm{Y}$. and Fu, Q.: Observed poleward expansion of the Hadley circulation since 1979, Atmos. Chem. Phys., 7, 5229-5236, doi:10.5194/acp-7-5229-2007, 2007.

Hudson, R. D., Andrade, M. F., Follette, M. B., and Frolov, A. D.: The total ozone field separated into meteorological regimes - Part II: Northern Hemisphere mid-latitude total ozone trends, Atmos. Chem. Phys., 6, 5183-5191, doi:10.5194/acp-6-5183-2006, 2006.

Johanson, C. M. and Fu, Q.: Hadley cell widening: model simulations versus observations, J. Climate, 22, 2713-2725, 2009.

King, M. D., Kaufman, Y. J., Menzel, W. P., and Tanre, D.: Remote sensing of cloud, aerosol, and water vapor properties from the moderate resolution imaging spectrometer (MODIS),

25 IEEE T. Geosci. Remote, 30, 2-27, 1992.

Lu, J., Vecchi, G. A., and Reichler, T.: Expansion of the Hadley cell under global warming, Geophys. Res. Lett., 34, L06805, doi:10.1029/2006GL028443, 2007.

Minnis, P., Trepte, Q. Z., Sun-Mack, S., Chen, Y., Doelling, D. R., Young, D. F., Spangenberg, D. A., Miller, W. F., Wielicki, B. A., Brown, R. R., Gibson, S. C., and Geier, E. B.: Cloud

\section{ACPD}

$11,16599-16610,2011$

\section{Sensing Hadley cell with space lidar}

W. Sun and B. Lin

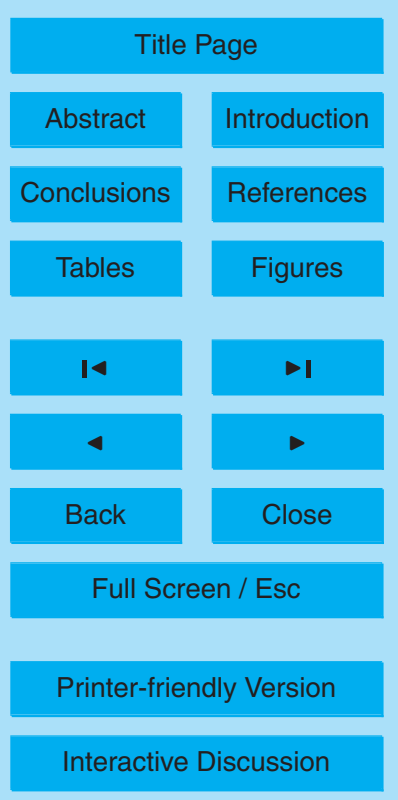


detection in nonpolar regions for CERES using TRMM VIRS and Terra and Aqua MODIS data, IEEE T. Geosci. Remote, 46, 3857-3884, 2008.

Nee, J. B., Len, C. N., Chen, W. N., and Lin, C. I.: Lidar observation of the cirrus cloud in the tropopause at Chung-Li $\left(25^{\circ} \mathrm{N}, 121^{\circ} \mathrm{E}\right)$, J. Atmos. Sci., 55, 2249-2257, 1998.

5 Platt, C. M. R., Young, S. A., Manson, P. J., Patterson, G. R., Marsden, S. C., and Austin, R. T.: The optical properties of equatorial cirrus from observations in the ARM pilot radiation observation experiment, J. Atmos. Sci., 55, 1977-1996, 1998.

Prabhakara, C., Kratz, D. P., Yoo, J. M., Dalu, G., and Vernekar, A.: Optically thin cirrus clouds: radiative impact on the warm pool, J. Quant. Spectrosc. Ra., 49, 467-483, 1993.

10 Quan, X. W., Diaz, H. F., and Hoerling, M. P. : Change in the tropical Hadley cell since 1950, in: The Hadley Circulation: Present, Past, and Future, Advances in Global Change Research, 21, edited by: Diaz, H. F. and Bradley, R. S., Springer, The Netherlands, doi:10.1007/978-14020-2944-8, 85-120, 2004.

Seidel, D. J. and Randel, W. J.: Recent widening of the tropical belt: evidence from tropopause observations, J. Geophys. Res., 112, D20113, doi:10.1029/2007JD008861, 2007.

Seidel, D. J., Fu, Q., Randel, W. J., and Reichler, T. J.: Widening of the tropical belt in a changing climate, Nature Geosci., 1, 21-24, 2007.

Spinhirne, J. D., Hart, W. D., and Hlavka, D. L.: Cirrus infrared parameters and shortwave reflectance relations from observations, J. Atmos. Sci., 53, 1438-1458, 1996.

20 Stephens, G. L., Vane, D. G., Boain, R. J., Mace, G. G., Sassen, K., Wang, Z., Illingworth, A. J., O'Connor, E. J., Rossow, W. B., Durden, S. L., Miller, S. D., Austin, R. T., Benedetti, A., Mitrescu, C., and the CloudSat Science Team: The CloudSat mission and the A-TRAIN: a new dimension to space-based observations of clouds and precipitation, B. Am. Meteorol. Soc., 83, 1771-1790, 2002.

Wang, P. H., McCormick, M. P., Poole, L. R., Chu, W. P., Yue, G. K., Kent, G. S., and Skeens, K. M.: Tropical high cloud characteristics derived from SAGE II extinction measurements, Atmos. Res., 34, 53-83, 1994.

Wielicki, B. A., Barkstrom, B. R., Harrison, E. F., Lee, R. B., Smith, G. L., and Cooper, J. E.: Clouds and the Earth's Radiant Energy System (CERES): an Earth observing system exper30 iment, B. Amer. Meteorol. Soc., 77, 853-868, 1996.

Winker, D. M. and Trepte, C. R.: Laminar cirrus observed near the tropical tropopause by LITE, Geophys. Res. Lett., 25, 3351-3354, 1998.

Winker, D. M., Pelon, J. R., and McCormick, M. P.: The CALIPSO mission: spaceborne lidar for

\section{Sensing Hadley cell with space lidar}

W. Sun and B. Lin

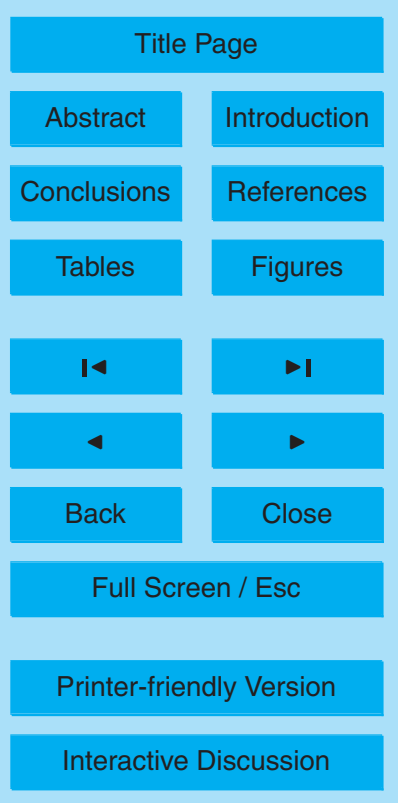


observation of aerosols and clouds, Proc. SPIE, 4893, 1-11, 2003.

Wylie, D. P. and Menzel, W. P.: Eight years of high cloud statistics using HIRS, J. Climate, 12, 170-184, 1998.

\section{ACPD}

$11,16599-16610,2011$

\section{Sensing Hadley cell} with space lidar

W. Sun and B. Lin

Title Page

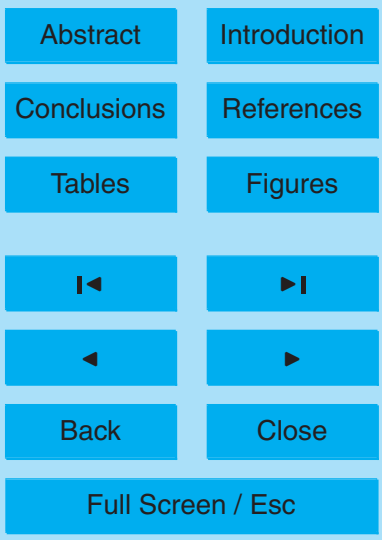

Printer-friendly Version

Interactive Discussion 


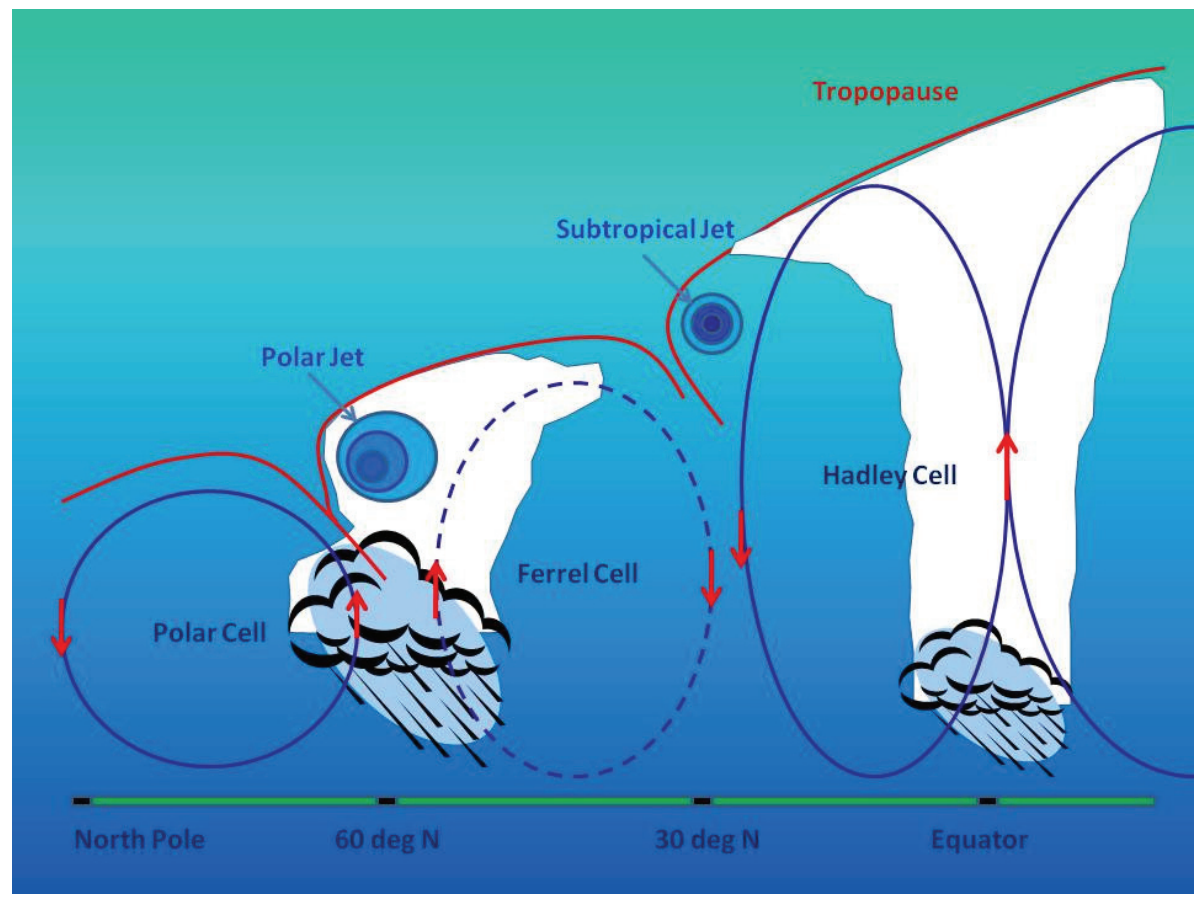

\section{ACPD}

11, 16599-16610, 2011

\section{Sensing Hadley cell} with space lidar

\section{W. Sun and B. Lin}

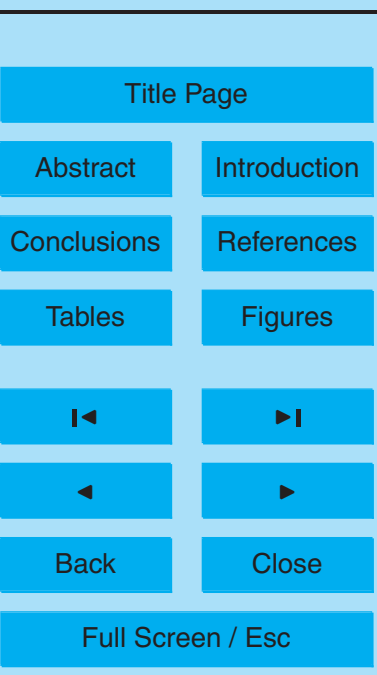

Printer-friendly Version

Fig. 1. Illustration of general circulation cells.

Interactive Discussion

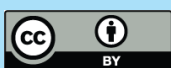


$532 \mathrm{~nm}$ Total Attenuated Backscatter, $\mathrm{km}^{-1} \mathrm{sr}^{-1} \quad$ UTC: 2007-09-20 18:14:08.2 to 2007-09-20 18:27:36.8 Version: 3.01 Nominal Nighttime

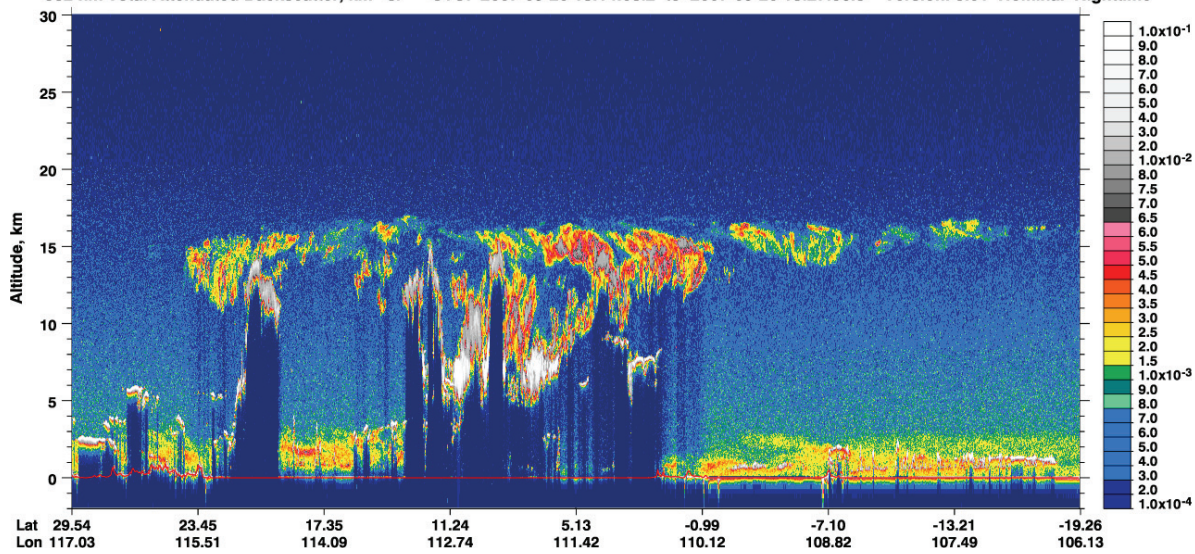

Fig. 2. Total attenuated backscatter at $532 \mathrm{~nm}$ from CALIPSO lidar. Super-thin cloud layers can be seen over and between thick clouds.

\section{ACPD}

$11,16599-16610,2011$

\section{Sensing Hadley cell} with space lidar

\section{W. Sun and B. Lin}

Title Page

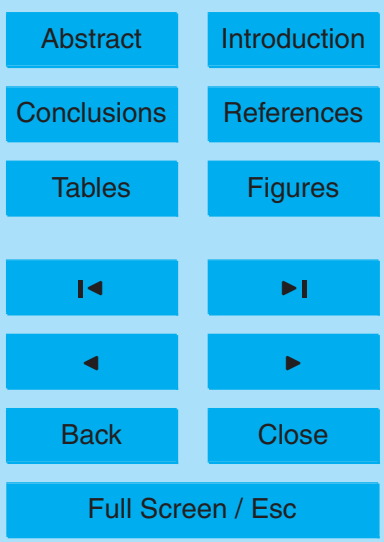

Printer-friendly Version

Interactive Discussion 


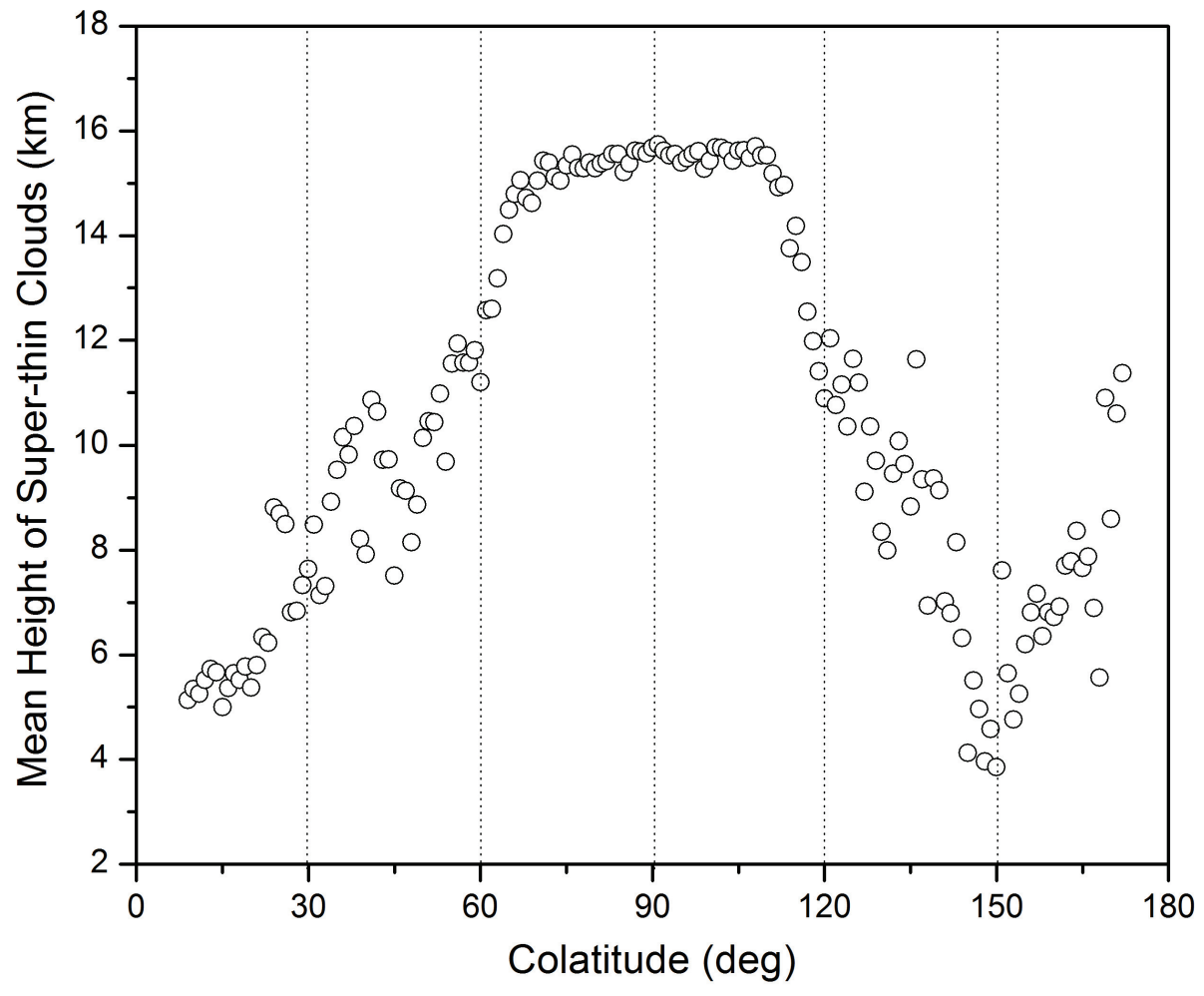

Fig. 3. The one-year zonal mean of the maximum height of the super-thin clouds for nighttime oceans.

\section{ACPD}

$11,16599-16610,2011$

Sensing Hadley cell with space lidar

W. Sun and B. Lin

Title Page

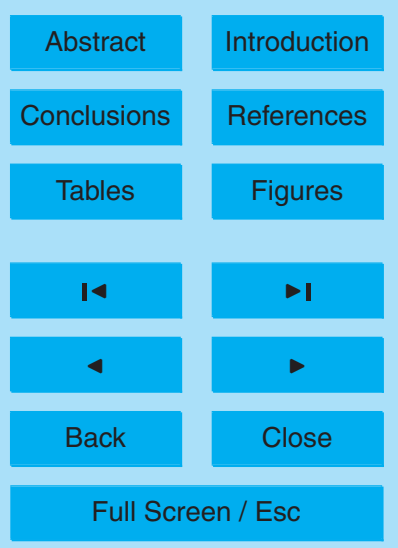

Printer-friendly Version

Interactive Discussion 


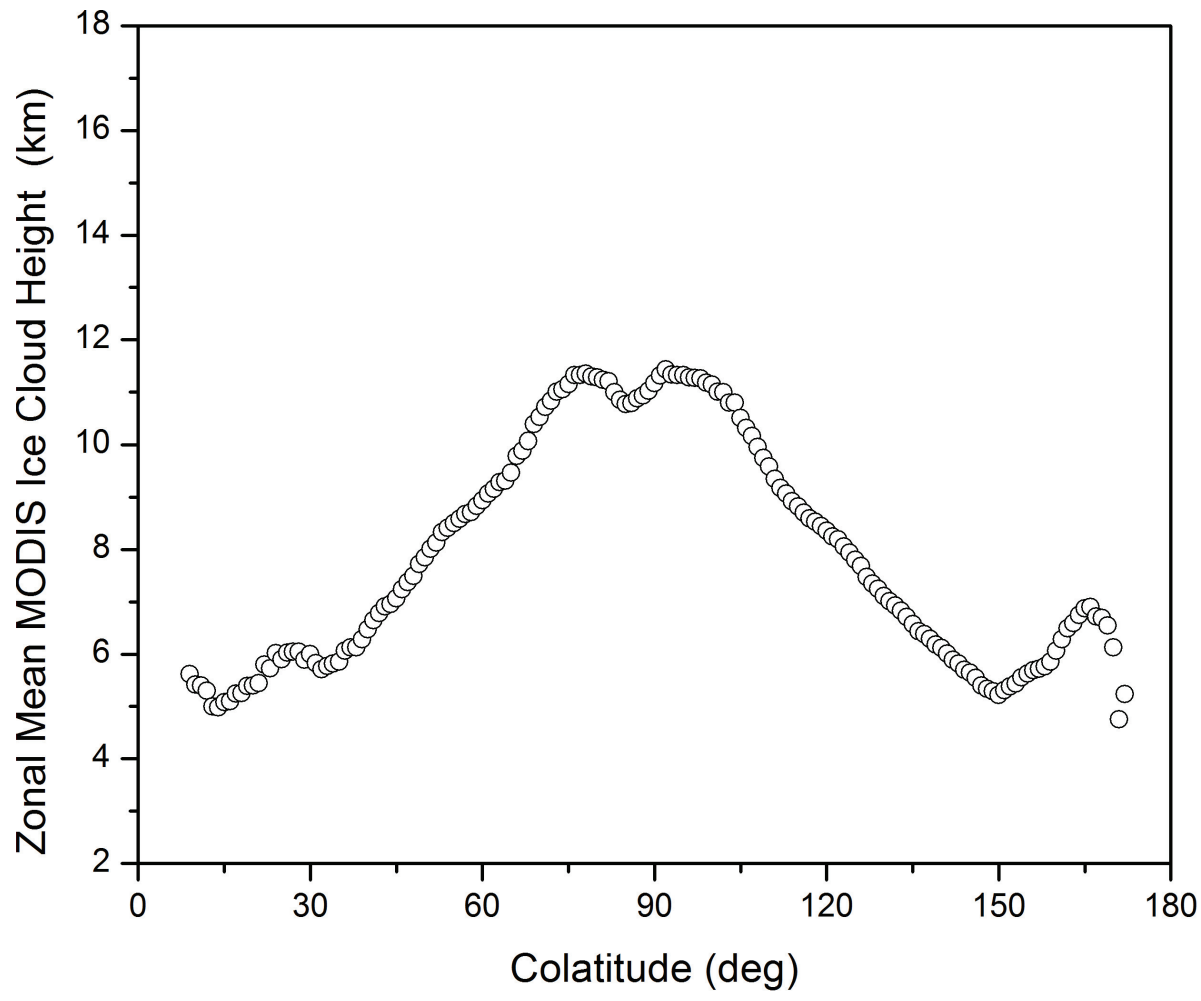

$11,16599-16610,2011$

\section{Sensing Hadley cell} with space lidar

W. Sun and B. Lin

Title Page

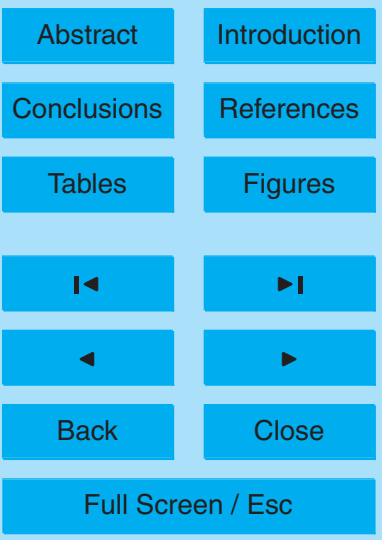

Printer-friendly Version

Fig. 4. The one-year zonal mean of the ice cloud height from MODIS.

Interactive Discussion

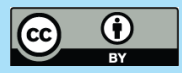

